\title{
Utilização Sustentável da Palha de Cana de Açúcar: Avaliação das Tecnologias Comercialmente Disponíveis para o seu Processamento em Biorrefinarias
}

\author{
Mauro D. Berni (PQ), Danilo S. Braz (IC)
}

\begin{abstract}
Resumo
A queima da palha da cana de açúcar antes da colheita é uma ação muito comum nos canaviais brasileiros, sendo, entretanto, bastante prejudicial ao meio ambiente e à saúde da população. Com a proibição dessa prática em algumas áreas do estado de São Paulo já a partir de 2015, torna-se necessário destinar tal resíduo a um processamento viável, tanto do ponto de vista econômico como técnico. Dessa forma, a criação de um portfólio com as tecnologias disponíveis para aproveitar a palha da cana (objetivo desse trabalho), seja para fins energéticos ou obtenção de bioprodutos, é de grande pertinência para nortear a utilização desse resíduo nas biorrefinarias paulistas.
\end{abstract}

Palavras Chave: Biorrefinarias, Tecnologias, Sustentabilidade

\section{Introdução}

No Brasil a cana de açúcar sempre figurou como uma das principais culturas nacionais. Atualmente o país é o maior produtor mundial de cana e maior exportador de açúcar e etano ${ }^{[1]}$.

Com a estipulação do Protocolo Agroambiental do Estado de São Paulo, o qual proíbe a queima da palha para colheita da cana em áreas mecanizáveis já em 2015, haverá grande acúmulo desse resíduo nos canaviais paulistas ${ }^{[2]}$.

Dessa maneira, o objetivo desse trabalho foi realizar um levantamento das tecnologias disponíveis para processar a palha da cana, com as quais se pode obter energia ou bioprodutos.

\section{Resultados e Discussão}

A manutenção da palha da cana no solo dos canaviais é importante para conservá-lo, na medida em que evita problemas de erosão, assim como auxilia na preservação da umidade do solo. Contudo, o grande acúmulo desse resíduo tem seus efeitos negativos, podendo provocar incêndios e a proliferação de pragas ${ }^{[3]}$.

Em relação aos processamentos para fins energéticos existem diversas formas: gaseificação, pirólise, liquefação, briquetagem (combustível sólido), biodigestão, combustão (queima em caldeiras) e etanol 2G. As três primeiras encontram-se em desenvolvimento de escala piloto, enquanto as outras já são realidades comerciais, onde destaca-se, além da produção de etanol de segunda geração (mais conhecida), a tecnologia de biodigestão desenvolvida e utilizada pela GEO Energética em sua planta no estado do Paraná, onde o biogás gerado pode ser convertido em energia elétrica ou biometano (biocombustível automotivo) ${ }^{[4]}$.
Já para bioprodutos, podem-se citar utilizações como: adsorvente de corantes e metais pesados, fibra têxtil medicinal, aditivo para fibrocimento, forragem verde hidropônica (tipo de ração), papel, obtenção de carbeto de silício, ração animal e aditivo para tinta látex. Além disso, a palha pode ter usos mais simples, como: objetos decorativos, cama de frango em granjas, confecção de chapéus, vasos e placas ${ }^{[5]}$.

\section{Conclusões}

Sabendo que haverá acúmulo de palha nos canaviais paulistas, podendo provocar problemas para a lavoura, recomenda-se retirar parte desse resíduo para utilizá-lo em alguma das tecnologias aqui apresentadas, enquanto o restante seria mantido no solo com o intuito de preservá-lo.

Nota-se então que um estudo de caso detalhado para o processamento escolhido é de suma importância, principalmente em relação à retirada e armazenamento desse material. Em síntese, faz-se necessário uma avaliação da sustentabilidade do projeto, contemplando os aspectos social, ambiental, econômico e técnico.

\section{Agradecimentos}

Ao $\mathrm{PIBIC} / \mathrm{CNPq}$ e ao SAE pelo apoio financeiro

\footnotetext{
${ }^{1}$ Lerayer, A.. Guia da cana-de-açúcar: Avanço científico beneficia o País. 2009.

${ }^{2}$ Dantas Filho, P. L.. Análise de custos na geração de energia com bagaço de cana-de-açúcar: um estudo de caso em quatro usinas de São Paulo. 2009.

Pinheiro, P. C. C.. Produção de carvão vegetal em pequena escala. 2010

${ }^{4}$ Dantas, F.. GEO Energética oferece tecnologia para a produção de biogás. Jornal da Bioenergia. 2014, Ano 8, No 90, p. 13

${ }^{5}$ Cosentino, J. A. S. e Souza, J. L. G.. Uso da palha da cana de açúcar para fins não energéticos. 2007.
} 